\title{
PERTANGGUNGJAWABAN BANK SEBAGAI KORPORASI TERHADAP TERJADINYA FRAUD
}

\section{RESPONSIBILITY OF THE BANK AS CORPORATE AGAINST OCCURRENCE OF FRAUD}

\section{Adi Atmaka dan Martin Roestamy}

\author{
Program Studi Hukum Sekolah Pascasarjana \\ Universitas Djuanda Bogor \\ Jl. Tol Ciawi No. 1, Kotak Pos 35, Bogor 16720. \\ Korespondensi : Adi Atmaka, Telp. - \\ e-mail : adi.atmaka@unida.ac.id
}

\begin{abstract}
Jurnal Living Law, Vol. 11, No. 1 , 2019

hlm. 13-22

Abstract : Operations of crimes committed by bank burglars must be immediately anticipated by the legal apparatus in Indonesia quickly and carefully so that the law does not look weak. At present the development of criminal legal responsibility has begun to expand, in the concept of criminal law, accountability can not only be requested from individuals, but also corporately. The obstacle is the concept of accountability of various corporate modes of law enforcement in Indonesia, so far it has not been utilized, besides the concept of corporate responsibility is not yet widely known, this concept is also still in the gray domain. Identification of this research are: 1) How is the bank's responsibility as a corporation for fraud and fraud ?. 2) What is the legal protection of bank customers who are victims of fraud? The research method used in this study is a normative juridical approach. The results of this study are: 1) Bank Indonesia as the holder of the Indonesian banking authority in an effort to meet applicable standards in the banking sector has prioritized programs related to customer protection, handling customer complaints, and including handling the establishment of independent banking mediation institutions, 2) In banking practice, a provision applies that customers who will save their funds in a bank are not free. The customer has the right to receive interest on funds deposited with the bank.
\end{abstract}

Keywords : Legal Protection, Fraud, Banking.

Abstrak : Operandi kejahatan yang dilakukan oleh pembobol bank harus segera diantisipasi oleh aparatur hukum di Indonesia dengan cepat dan cermat agar hukum tidak terlihat lemah. Saat ini perkembangan pertanggungjawaban hukum secara pidana sudah mulai meluas, tidak hanya bisa dimintakan kepada perseorangan, tetapi juga secara korporasi. Kendalanya adalah konsep pertanggungjawaban berbagai modus korporasi dalam penegakan hukum di Indonesia, hingga saat ini belum begitu dimanfaatkan. Selain konsep ini belum begitu dikenal luas, juga masih dalam ranah abu-abu. Identifikasi penelitian ini yaitu: 1) Bagaimana pertanggungjawaban bank sebagai korporasi atas terjadinya pembobolan dan penipuan (fraud)?; 2) Bagaimana perlindungan hukum terhadap nasabah bank korban terjadinya fraud?. Metode penelitian yang digunakan dalam penelitian ini adalah pendekatan yuridis normatif. Hasil dari penelitian ini yaitu: 1) Bank Indonesia sebagai pemegang otoritas perbankan Indonesia dalam upaya memenuhi standar yang berlaku dalam bidang perbankan telah memprioritaskan program-program terkait terhadap perlindungan nasabah, penanganan pengaduan nasabah, dan termasuk penanganan pembentukan lembaga mediasi perbankan yang independen, 2) Dalam praktik perbankan berlaku ketentuan bahwa nasabah yang akan menyimpan dananya dilakukan bukan dengan cuma-cuma. Nasabah berhak untuk menerima bunga atas dana yang disimpan pada bank tersebut.

Kata Kunci : Perlindungan Hukum, Fraud, Perbankan. 


\section{PENDAHULUAN}

Di Indonesia lembaga keuangan memiliki misi dan fungsi khusus selain fungsi yang lazim. Bank dituntut untuk berperan sebagai agen pembangunan yaitu sebagai lembaga yang bertujuan mendukung pelaksanaan pembangunan dan hasil-hasilnya, pertumbuhan ekonomi dan stabilitas nasional kearah peningkatan taraf hidup rakyat banyak. ${ }^{1}$

Namun dari semua itu yang terpenting adalah bagaimana usaha perbankan nasional melaksanakan komitmennya secara konsisten, profesional dan transparan. Hal ini merupakan persyaratan yang mutlak untuk membangun kembali kepercayaan terhadap dunia perbankan nasional.

Langkah-langkah seperti yang disebutkan di atas dilakukan untuk mempertahankan atau menyelamatkan bank sebagai lembaga kepercayaan masyarakat. Dengan adanya bank-bank yang sakit membuat pemerintah akhirnya mengambil suatu kebijaksanaan untuk melikuidasi bank-bank yang sakit tersebut, karena bank-bank yang sakit tersebut dapat dikhawatirkan akan membahayakan perekonomian bangsa.

Kebijaksanaan pemerintah untuk melikuidasi bank tersebut tentunya akan mempengaruhi peredaran uang dan itu dapat merugikan masyarakat, khususnya nasabah penyimpan dana. Kerugian tersebut ditanggung oleh bank yang bersangkutan, yang akhirnya bisa ditanggung kreditur maupun nasabah.

Banyaknya dana yang dapat dihimpun oleh bank dari masyarakat identik dengan banyaknya nasabah bank, maksudnya bahwa semakin banyak bank yang dapat menarik nasabah, maka bank akan mendapat dana yang semakin besar pula. Oleh karena itu banyak masyarakat menjadi nasabah bank, maka perlu adanya perlindungan hukum bagi nasabah penyimpan dana.
Kegiatan perbankan lebih banyak tergantung kepada dana masyarakat sehingga perlu dijamin kepastian keamanannya. Selain itu, penyaluran dana perbankan merupakan bisnis beresiko tinggi, yang apabila tidak dikelolah dengan baik dapat menganggu tidak hanya kelangsungan usaha bank itu sendiri, namun juga sistem perbankan dan kestabilan moneter.

Dari uraian latar belakang masalah tersebut di atas maka penulis dalam penelitian ini mengambil judul tentang: "PERTANGGUNGJAWABAN SEBAGAI KORPORASI TERHADAP TERJADINYA FRAUD".

Berdasarkan uraian latar belakang masalah di atas, maka penulis dapat mengidentifikasi masalah sebagai berikut:

1. Bagaimana pertanggungjawaban bank sebagai korporasi atas terjadinya pembobolan dan penipuan (fraud)?

2. Bagaimana perlindungan hukum terhadap nasabah bank korban terjadinya fraud?

\section{METODE PENELITIAN}

Metode penelitian yang digunakan dalam penelitian ini adalah pendekatan yuridis normatif, yaitu hukum dikonsepsikan sebagai norma, kaidah, asas atau dogma-dogma/yurisprudensi.

\section{PEMBAHASAN}

\section{A. PERTANGGUNGJAWABAN BANK SEBAGAI KORPORASI ATAS TERJADINYA PEMBOBOLAN DAN PENIPUAN (FRAUD)}

Pelanggaran hak nasabah oleh bank dapat diselesaikan melalui jalur hukum. Namun ketika kita kembali sadarkan terhadap nilai-nilai negara hukum Pancasila dan Undang-undang Dasar 1945 yang mengedepankan asas musyawarah, forum mediasi merupakan dimensi yang juga penting. ${ }^{2}$

\footnotetext{
2 Lukman Santoso Az, Op.Cit., Hlm. 126.
}

\footnotetext{
${ }^{1}$ H. Budi Untung, Kredit Perbankan di Indonesia, Yogyakarta: ANDI, 2005, Hlm. 14.
} 
Artinya, ketika sengketa perbankan masih dapat diselesaikan secara baik dan tetap menguntungkan kedua belak pihak, maka jalur hukum atau pengadilan dapat dikesampingkan/dihentikan. Hal ini juga terkait dengan prinsip penyelesaian sengketa secara murah, sederhana dan cepat.

Hadirnya upaya tersebut tentu tidak terlepas dari hubungan timbal balik antara nasabah dan bank, baik itu nasabah penyimpan dalam bentuk tabungan maupun deposito atau nasabah lain. Hubungan timbal balik ini dapat berupa pemberian bunga oleh pihak bank terhadap simpanan dari nasabah, serta kewajibankewajiban nasabah untuk memenuhi ketentuan system administrasi tertentu apabila hendak mengambil atau menyimpan uang.

Selain itu, sebagai upaya peningkatan dan pemberdayaan nasabah, tentu bank sebagai pelaku usaha harus memberikan layanan penyelesaian dan infrastruktur atas berbagai keluhan dan pengaduan nasabah. Media penyelesaian ini juga harus memenuhi standar waktu dan pelayanan, Artinya dapat berlaku secara efektif dan efesien.

Bank Indonesia sebagai pemegang otoritas perbankan Indonesia dalam upaya memenuhi standar tersebut juga telah memprioritaskan program-program terkait perlindungan nasabah, termasuk penanganan pengaduan nasabah, termasuk penanganan perbankanan pembentukan lembaga mediasi perbankan independen.

Dalam ranah hukum, seorang tentu harus bertanggung jawab terhadap kerugian yang diakibatkan oleh perbuatan yang bertentangan dengan hukum dari orang lain. hal ini disebut tanggung jawab kwalitatif, yaitu orang yang bertanggung jawab karena orang itu memiliki suatu kwalitas tertentu.

Sesuai dengan penerapan hukum di Indonesia, seorang konsumen yang dilakukan oleh pelaku usaha, termasuk nasabah kepada bank, dapat menggugat pihak yang menimbulkan kerugian atas produk dan jasanya tersebut. Kwalifikasi gugatan yang lazim adalah wanprestasi atau perbuatan melawan hukum.

Dalam gugatan adanya wanprestasi, maka terdapat hubungan kontraktual antara konsumen dan pelaku usaha/produsen. Kerugian yang dialami oleh nasabah tidak lain adalah karena tidak dilaksanakan prestasi oleh bank sebagai pelaku usaha.

Apabila tidak terdapat hubungan kontraktual antara nasabah dan bank, maka tidak ada tanggung jawab (hukum) pelaku usaha nasabah. Hal inilah yang dikenal dengan doktrin yang mengandung prinsip "tidak ada hubungan kontraktual, tidak ada tanggung jawab".

Sedangkan dalam gugatan berdasarkan perbuatan melawan hukum, hubungan kontraktual tidaklah disyaratkan. Dalam hal ini nasabah haruslah membuktikan adanya unsur-unsur:

1. Adanya perbuatan melawan hukum,

2. Adanya kesalahan/kelalaian pelaku usaha,

3. Adanya kerugian yang dialami oleh konsumen,

4. Adanya hubungan kausal antara perbuatan melawan hukum dan kerugian yang dialami oleh konsumen.

Pada Undang-undang Nomor 8 Tahun 1999 tentang Perlindungan Konsumen (UUPK), dalam konteks pertanggungjawaban pelaku usaha atas gugatan nasabah ini, Ketentuan ini tidak berlaku apabila pelaku usaha dapat membuktikan bahwa kerugian tersebut merupakan atau sebagai akibat kesalahan konsumen. Sehingga, pembuktian terhadap ada tidaknya unsur kesalahan dalam gugatan- gugatan ganti rugi, merupakan beban dan tanggung jawab pelaku usaha (Pasal 28 UUPK).

Peraturan Bank Indonesia Nomor 5/8/PBI/2003 tentang Penerapan Manajemen Risiko Bagi Bank Umum (selanjutnya disingkat PBI No. 5/8/ PBI/2003). Perlunya manajemen resiko ini ada kaitannya dengan kepercayaan masyarakat terhadap dunia perbankan, 
sehingga perlu menghindari potensi terjadinya suatu peristiwa (events) yang dapat menimbulkan kerugian bank. ${ }^{3}$

Sedangkan mengenai manajemen resiko merupakan serangkaian prosedur dan metodologi yang digunakan untuk mengidentifikasi, mengukur, memantau, dan mengendalikan resiko yang timbul dari kegiatan usaha bank. Perihal manajemen resiko, bank wajib menerapkan Manajemen Resiko secara efektif.

Penerapan Manajemen Resiko sebagaimana dimaksud dalam ayat (1) sekurang-kurangnya mencakup:

a. Pengawasan aktif dewan Komisaris dan Direksi;

b. Kecukupan kebijakan, prosedur, dan penetapan limit;

c. Kecukupan proses identifikasi, pengukuran, pemantauan dan pengendalian resiko serta sistem informasi Manajemen Resiko; dan

d. Sistem pengendalian intern yang menyeluruh sebagaimana Pasal 2 PBI No. 5/8/PBI/2003.

Resiko perbankan tersebut menurut Pasal 4 PBI No. 5/8/PBI/2003 meliputi:

(1) Resiko sebagaimana dimaksud dalam Pasal 2 mencakup:

a. Risiko Kredit;

b. Resiko Pasar;

c. Risiko Likuiditas;

d. Resiko Operasional;

e. Resiko Hukum;

f. Resiko Reputasi;

g. Resiko Strategik;

h. Resiko Kepatuhan.

(2) Bank yang memiliki ukuran dan kompleksitas usaha yang tinggi wajib menerapkan Manajemen Resiko sebagaimana dimaksud dalam Pasal 2 ayat (2) untuk seluruh jenis risiko sebagaimana dimaksud dalam ayat (1).

Mengenai pihak yang berwenang dan bertanggung jawab atas resiko yang terjadi adalah komisaris dan direksi. Menurut

3 Muhammad Djumhana, Hukum Perbankan di Indonesia, Bandung: Citra Aditya Bakti, 2000, Hlm. 370-371.
Pasal 6 PBI No. 5/8/PBI/2003 menentukan sebagai berikut:

Wewenang dan tanggung jawab bagi dewan komisaris sekurang-kurangnya:

a. Menyetujui dan mengevaluasi kebijakan Manajemen Resiko;

b. Mengevaluasi pertanggungjawaban Direksi atas pelaksanaan kebijakan Manajemen Resiko sebagaimana dimaksud dalam huruf a;

c. Mengevaluasi dan memutuskan permohonan Direksi yang berkaitan dengan transaksi yang memerlukan persetujuan dewan Komisaris.

\section{B. PERLINDUNGAN HUKUM TERHADAP NASABAH BANK KORBAN TERJADINYA FRAUD}

Kepentingan konsumen, termasuk pula dalam hal ini nasabah, secara rinci termuat dalam Revolusi PBB Nomor 39/248 Tahun 1985. Dalam sidang umum PBB ke-106 yang digelar tanggal 9 April 1985. Dalam Pasal 4 Bab III Undang-undang Nomor 8 Tahun 1999 tentang Perlindungan Konsumen, Secara spesifik, hak-hak konsumen, terutama kepentingan hukumnya, telah termuat dalam Undangundang Nomor 8 Tahun 1999, dalam hal itu merupakan kepentingan yang mutlak dan sah bagi masyarakat Indonesia sebagai konsumen.

Suatu hal yang tidak adil bagi konsumen bila kepentingan konsumen tidak seimbang dan tidak dihargai sebagaimana penghargaan terhadap kalangan pengusaha. Dalam konteks itu, nasabah memiliki hak secara spesifik, yakni sebagai berikut:

1. Nasabah berhak untuk mengetahui secara terperinci tentang produkproduk perbankan yang ditawarkan. Hak ini merupakan hak utama dari nasabah, karena tanpa penjelasan terperinci dari bank melalui customer service-nya, maka sangat sulit nasabah untuk memilih produk perbankan apa yang sesuai dengan kehendaknya. Hakhak apa saja yang akan diterima oleh 
nasabah apabila nasabah mau menyerahkan dananya kepada bank untuk dikelola.

2. Nasabah berhak untuk mendapatkan bunga atas produk tabungan dan deposito yang telah diperjanjikan terlebih dahulu.

Besarnya bunga ini dapat dilihat pada ketentuan yang berlaku pada setiap bank menurut produk perbankan yang ada. Bagi bank berdasarkan prinsip syariah nasabah penyimpan dana berhak atas bagian keuntungan dana yang disimpan. Sedangkan kewajiban nasabah, diatur dalam pasal 5 Undang-undang Nomor 8 Tahun 1999, yang menyatakan bahwa kewajiban konsumen, yaitu:

1. Membaca atau mengikuti petunjuk informasi dan prosedur pemakaian atau pemanfaatan barang dan/atau jasa, demi keamanan dan keselamatan;

2. beretikad baik dalam melakukan transaksi pembelian barang dan/atau jasa;

3. membayar sesuai dengan nilai tukar yang disepakati;

4. mengikuti upaya penyelesaian hukum sengketa perlindungan konsumen secara patuh.

Kewajiban nasabah dalam hubungannya dengan bank, pada umumnya harus memerhatikan wujud bank tersebut dengan mewakilkan pemantauan dan analisis terhadap indikator-indikator penting yang bisa mendeteksi gejala dari kemungkinan timbulnya masalah pada bank tersebut.

Adapun hal-hal yang harus diperhatikan oleh seorang nasabah dalam hubungannya dengan sebuah bank adalah sebagai berikut:

a. Menilai kewajaran terhadap tingkat suku bunga produk tabungan dan deposito, yang dikaitkan dengan tingkat suku bunga pasar yang umumnya berlaku. Apabila tingkat suku bunga tinggi produk tabungan dan deposito terlalu tinggi bila dibandingkan dengan tingkat suku bunga pasar pada umumnya, maka semakin besar resiko yang harus dipikul oleh seorang nasabah.

b. Nasabah harus menilai akan kemampuan bank tersebut dalam mencetak laba setelah kena pajak selama 2 tahun berturut-turut. Laba tersebut harus merupakan laba yang didapat dalam pendapat bank, bukan dari penjualan aktiva bank tersebut.

c. Nasabah juga harus memerhatikan ekspansi kredit yang dilakukan bank tersebut, juga harus dengan net interest margin (selisih antara pendapatan dan biaya bunga). Artinya bila ekspansi kreditnya tinggi dan NIMnya rendah, berarti bank tersebut dalam kondisi yang tidak baik, begitu sebaliknya.

d. Nasabah juga harus memerhatikan loan deposit ratio (perbandingan antara peminjam yang diberikan sebelum dikurangi perselisihan piutang ragu-ragu dan sumber dana pihak ketiga). LDR yang baik sesuai dengan ketentuan Bank Indonesia, yakni antara 70-80\%. Bila LDR-nya lebih dari $110 \%$ berarti bank tersebut kurang baik.

e. Lihat pula apakah dana pihak ketiga yang ditempatkan oleh bank tersebut ditempatkan dalam aktiva produktif.

f. Perhatikan juga rasio antara modal bank tersebut dan asset bank.

Perlindungan bagi para nasabah penyimpan dana memang merupakan suatu hal yang bersifat mutlak bagi para pelaku bisnis perbankan. Selama ini, kurang terlindunginya para nasabah penyimpan saat ini memang dapat dirasakan sejak pertama kali nasabah penyimpan menyerahkan dana mereka pada bank yang dipercayai tersebut.

Ketidak berimbangan posisi hukum antara nasabah penyimpan dana dengan bank merupakan faktor utama dimunculkannya mengenai perlindungan dana nasabah penyimpan dana berdasarkan Undang-undang Republik Indonesia Nomor 24 Tahun 2004 tentang Lembaga Penjamin Simpanan (LPS). 
Lembaga tersebut nantinya diharapkan dapat menjadi lembaga yang memberikan jaminan terhadap dana nasabah penyimpan dan diharapkan dapat lebih baik dari yang selama ini pernah ada dalam hal menjamin dana pihak ketiga, baik dari segi kepastian hukum tentang dana simpanan nasabah pada suatu bank, maupun sisi pelayanan, dan secara hukum.

Lembaga tersebut dipayungi oleh peraturan perundang-undangan yang memadai, sehingga kelahiran dan keberadaannya dapat benar-benar dirasakan sangat bermanfaat bagi masyarakat secara umum dan nasabah penyimpan secara khusus.

Perlindungan hukum bagi rakyat Indonesia Philipus M. Hadjon mengatakan bahwa ada dua macam perlindungan hukum bagi rakyat, yaitu perlindungan hukum yang preventif bertujuan untuk mencegah terjadinya sengketa dan perlindungan hukum represif yang bertujuan untuk menyelesaikan sengketa. ${ }^{4}$

Di depan dijelaskan bahwa hubungan antara nasabah penyimpan dengan bank berdasarkan hubungan kontraktual, dimana dalam hubungan kontraktual ini hak-hak nasabah penyimpan lahir dari kontrak/perjanjian penyimpanan dana yang dibuat oleh bank dengan nasabah penyimpan sendiri. Selain itu hak-hak nasabah penyimpan juga diatur/diberikan oleh KUHPerdata maupun ketentuan hukum perbankan.

Hanya saja perjanjian penyimpanan dana dalam praktik isinya ditentukan oleh pihak bank, seperti berapa besarnya bunga simpanan, dan biasanya perjanjian penyimpanan dana merupakan perjanjian standar/baku yang biasanya terdapat ketentuan yang lebih menguntungkan pihak bank.

Selain itu atas tagihan simpanan pada bank tersebut nasabah penyimpan tidak mungkin memperjanjikan jaminan/agunan

4 Sulistyandary, Perlindungan Hukum Nasabah Korban Pembobolan Rekening (Bagian II), http://www.google.com, Diakses pada Tanggal 3 Februari 2018. atas pengembalian tagihan simpanannya seperti halnya dalam perjanjian kredit. Sehingga jika hal ini dihubungkan dengan perlindungan hukum terhadap nasabah penyimpan.

Maka dalam hubungan kontraktual ini bisa dikatakan perlindungan hukum terhadap nasabah penyimpan sangat kurang dibandingkan perlindungan hukum atas hak/tagihan bank terhadap nasabah peminjam dalam perjanjian kredit. Jika terjadi pelanggaran hak nasabah penyimpan oleh bank dalam hubungan kontraktual.

Seharusnya perlindungan hukum diberikan oleh perjanjian penyimpanan dana itu sendiri karena perjanjian adalah undang-undang bagi mereka yang membuatnya, sedang KUHPerdata memberikan hak-hak kepada nasabah penyimpan sebagaimana yang disebutkan antara lain dalam Pasal 1267 KUHPerdata.

Maka jika terjadi kasus dimana ketika nasabah penyimpan tabungan akan menarik tabungannya beserta bunga sesuai yang diperjanjikan melalui alat eletronik (misalnya ATM) dan jika ternyata tabungannya berkurang/habis karena pembobolan oleh pihak lain yang jelas bukan karena kesalahan nasabah penyimpan (biasanya bank perlu bukti untuk hal ini).

Maka nasabah penyimpan memperoleh perlindungan hukum dari Pasal 1267 KUHPerdata, artinya nasabah dapat menggunakan hak-haknya sesuai dengan Pasal tersebut. Dalam hubungan kontraktual ini sebenarnya nasabah penyimpan mendapatkan perlindungan hukum dalam bidang perdata.

Dalam perlindungan hukum perdata pada prinsipnya warga negara boleh mengatur sendiri menurut pandangannya hubungan satu sama lain (asas otonomi). Asas otonomi warga negara ini antara lain ialah kebebasan membuat kontrak (isi suatu persetujuan, pada dasarnya bebas dari campur tangan pembuat undangundang). 
Otonomi para warga negara dalam hukum privat itu mencakup juga, bahwa kepada para warga negara itu diserahkan, apakah mereka mempertahankan atau tidak mempertahankan haknya itu. Mengingat hubungan nasabah penyimpan dengan bank merupakan hubungan yang diatur dalam hukum perbankan dan jika dilihat pada ruang lingkup hukum perbankan termasuk dalam kategori campuran hukum privat dan hukum publik.

Maka jika dari sisi hukum perdata hubungan antara nasabah penyimpan dengan bank, nasabah penyimpan kurang terlindungi, maka seharusnya perlindungan hukum terhadap nasabah penyimpan dapat diberikan melalui hukum publik atas hakhaknya terhadap bank.

Dalam hubungan non kontraktual, hakhak nasabah penyimpan terhadap bank muncul karena adanya hukum tertulis (UU Perbankan, UU BI dan peraturan pelaksanaan) dan hukum tidak tertulis, hubungan non kontraktual yang diatur dalam UU Perbankan dan peraturan pelaksananya yaitu:

1. Hubungan kepercayaan;

2. Hubungan kerahasiaan;

3. Hubungan menjamin simpanan nasabah penyimpan;

4. Hubungan kepedulian terhadap resiko nasabah;

5. Hubungan kepedulian terhadap pengaduan nasabah.

Hal itu dapat diuraikan sebagai berikut: Hubungan Kepercayaan, hubungan ini tersimpul dari Pasal 1 angka 2, Pasal 1 angka 5 dan Pasal 3 UU Perbankan, bahwa bank adalah badan usaha yang menghimpun dana dari masyarakat dalam bentuk simpanan dan menyalurkannya kepada masyarakat dalam bentuk kredit dan/atau bentuk-bentuk lainnya dalam rangka meningkatkan taraf hidup rakyat banyak.

Fungsi utama perbankan Indonesia adalah sebagai penghimpun dan penyalur dana masyarakat. Simpanan adalah dana yang dipercayakan oleh masyarakat kepada bank berdasarkan perjanjian penyimpanan dana dalam bentuk Giro, Deposito, Tabungan dan/atau bentuk lainnya yang dipersamakan dengan itu.

Dari beberapa pasal tersebut dapat diketahui bahwa bank adalah lembaga perantara/intermediasi (intermediary institution), dimana bank menghimpun dana dari masyarakat dalam bentuk simpanan, disini muncul hubungan hukum antara bank (debitur) dengan nasabah penyimpan (kreditur), nasabah penyimpan mempercayakan dana simpanannya kepada bank untuk dikelolah, untuk itu nasabah penyimpan berhak atas pengembalian simpanan dengan bunga.

Kemudian oleh bank dana simpanan tersebut disalurkan kepada nasabah peminjam, disini muncul juga hubungan hukum antara bank (kreditur) dengan nasabah peminjam (debitur), bank menyalurkan dana simpanan kepada nasabah peminjam dalam bentuk kredit.

Artinya bank juga mempercayakan dana itu kepada nasabah peminjam untuk dikelola, dan untuk itu bank berhak atas pengembalian dana yang dipinjamkan dengan bunganya. Dengan demikian dari beberapa pasal tersebut tersimpul adanya suatu asas/prinsip kepercayaan (fiduciary) dalam pengaturan perbankan Indonesia.

Oleh karena lembaga intermediasi adalah merupakan kegiatan utama bank, maka keuntungan bank yang utama juga adalah selisih bunga pinjaman dengan bunga simpanan. Mengingat dari kegiatan utama bank tersebut pada akhirnya bertujuan untuk menunjang pelaksanaan pembangunan nasional dalam rangka meningkatkan pemerataan, pertumbuhan ekonomi, dan stabilitas nasional kearah peningkatan kesejahteraan rakyat banyak.

Maka kepada nasabah penyimpan yang telah mempercayakan dananya kepada bank perlu mendapatkan perlindungan hukum yang memadai. Perlindungan hukum tersebut diatur dalam Pasal 8 tentang pemberian kredit, Pasal 16 tentang perizinan dan 29 tentang pembinaan dan pengawasan perbankan, artinya bank harus menjalankan kegiatan usaha dengan 
prinsip kehati-hatian. Kemudian pembinaan dan pengawasan bank oleh Bank Indonesia sebenarnya merupakan suatu ketentuan dalam Undang-undang Perbankan yang pada akhirnya juga bertujuan untuk memberikan perlindungan terhadap bank yang bersangkutan dan nasabah penyimpan, dan jika terjadi pelanggaran kewajiban bank yang berkaitan dengan ketentuan yang mengatur prinsip kehati-hatian, pembinaan dan pengawasan ini.

Bank dikenai sanksi administratif sesuai dengan Pasal 52 Undang-undang Perbankan yang berupa teguran tertulis, dan pelanggaran itu dapat diperhitungkan dengan komponen tingkat kesehatan bank, bahkan bank dapat diberikan sanksi pencabutan izin usaha, dan dengan adanya ketentuan Pasal 49 ayat (2) huruf b Undang-undang Perbankan maka Direksi dari bank yang bersangkutan dapat diadukan oleh nasabah sebagai telah melaksanakan tindak pidana dan dijatuhi sanksi pidana.

Jika dilihat kasus-kasus pembobolan uang nasabah bank seperti di Citibank yang melibatkan orang dalam atau pegawai bank sendiri, maka pada hakekatnya pembobolan uang nasabah bank, disebabkan karena bank kurang menjalankan kegiatan usaha dengan prinsip kehati-hatian, kurang memiliki pengawasan internal yang cukup untuk kompleksitas kegiatan usahanya, oleh karena itu agar kasus-kasus yang demikian tidak terulang atau dapat diminimalisir, maka sudah seharusnya bank menjalankan kegiatan usahanya dengan prinsip kehatihatian dan meningkatkan pengawasan internalnya.

\section{KESIMPULAN}

Berdasarkan hasil penelitian di atas, penulis dapat mengambil kesimpulan sebagai berikut:

1. Bank Indonesia sebagai pemegang otoritas perbankan Indonesia dalam upaya memenuhi standar yang berlaku dalam bidang perbankan telah memprioritaskan program-program terkait terhadap perlindungan nasabah, penanganan pengaduan nasabah, dan termasuk penanganan pembentukan lembaga mediasi perbankan yang independen. Perlunya manajemen resiko ini sebagai bentuk yang ada kaitannya dengan kepercayaan masyarakat terhadap dunia perbankan, sehingga perlu menghindari potensi terjadinya suatu peristiwa (events) yang dapat menimbulkan kerugian bank.

2. Dalam praktik perbankan berlaku ketentuan bahwa nasabah yang akan menyimpan dananya di suatu bank dilakukan bukan dengan cuma-cuma. Nasabah berhak untuk menerima bunga atas dana yang disimpan pada bank tersebut. Secara yuridis, hubungan antara bank dengan nasabah penyimpan adalah berkaitan satu sama lain, di satu pihak nasabah menginginkan dana yang dimilikinya aman dengan dititipkan pada bank, di sisi yang lain bank mengharapkan masyarakat menitipkan dananya pada bank yang bersangkutan dengan harapan dana yang terkumpul nantinya dapat disalurkan melalui kredit dan bank memperoleh imbalan bunga dari pihak debitur.

\section{SARAN}

1. Pihak pemerintah agar lebih memperhatikan kegiatan dari bankbank terutama bagi Bank Indonesia sebagai pembina dan pengawas terhadap kegiatan perbankan agar dalam hal ini pihak bank lebih bertanggung jawab dan memperhatikan apa yang menjadi hakhak dari pihak nasabah dan apabila bank-bank pelaksana melalaikan kewajiban dan tanggung jawab maka perlu ada sanksi yang tegas terhadap bank tersebut.

2. Mengingat perlindungan hukum terhadap nasabah penyimpan dana masih sangat kurang dan sering tidak 
melakukan kewajibannya sehingga nasabah merasakan banyak kerugian. Untuk itu kepada pihak bank agar lebih lagi meningkatkan perlindungan hukum termasuk hak dan kewajiban nasabah bank bisa lebih terlindungi.

\section{UCAPAN TERIMA KASIH}

\section{DAFTAR PUSTAKA}

\section{A. Buku:}

Djoni S. Gazali dan Rachmadi Usman, Hukum Perbankan, Jakarta: Sinar Grafika, 2010.

H. Budi Untung, Kredit Perbankan di Indonesia, Yogyakarta: ANDI, 2005.

Hermansyah, Hukum Perbankan Nasional Indonesia: Ditinjau Menurut Undang-undang No. 7 Tahun 1992 tentang Perbankan Sebagaimana Telah Diubah dengan Undang-undang No. 10 Tahun 1998, dan Undang-undang No. 23 Tahun 1999 jo Undang-undang No. 3 Tahun 2004 tentang Bank Indonesia, Cetakan Kedua, Jakarta: Kencana Prenada Media Group, 2005.

Mochtar Kusumaatmadja, Fungsi dan Perkembangan Hukum dalam Pembangunan Nasional, Binacipta: Bandung, 1976.

Muhamad Djumhana, Hukum Perbankan di Indonesia, Bandung: PT Citra Aditya Bakti, 2006.

Sentosa Sembiring, Hukum Perbankan, Bandung: CV Mandar Maju, 2008.

Sutan Remy Sjahdeini, Himpunan Tulisan Kapita Selekta Hukum Perbankan, Jilid 1, Jakarta: UI Press, 2006.

\section{B. Peraturan Perundang-undangan}

Undang-undang Dasar Negara Republik Indonesia Tahun 1945.

Undang-undang Nomor 10 Tahun 1998 Tentang Perubahan Atas Undang-undang Nomor 7 Tahun 1992 tentang Perbankan.

Undang-undang Nomor 8 Tahun 1999 tentang Perlindungan Konsumen.

Undang-undang Nomor 3 Tahun 2004 tentang Bank Indonesia.

Undang-undang Nomor 11 Tahun 2008 tentang Informasi dan Transaksi Elektronik.

Putusan Kasasi MA Nomor 702 K/Pid.Sus/2014.

\section{Internet}


"Kenali Modus Pembobolan Bank", http:// berita.liputan6.com/ hukrim/201104/327433/kenali_modus_pembobolan_bank. Diakses pada tanggal 8 Agustus 2017.

Muliaman D. Hadad, "Perlindungan dan Pemberdayaan Nasabah Bank Dalam Arsitektur Perbankan Indonesia", http://www.google.com, Diakses pada tanggal 8 Agustus 2017.

Rizki Syarief, "Nasabah Bank Victoria Minta Kasusnya Segera Diselesaikan", http://www.detiknews.com/read/2011/04/05/150633/1609012/10/korbanpembobolan-rekening-rp-7-m-minta-bi-periksa-bank-victoria?n991102605. Diakses pada tanggal 8 Agustus 2017.

Sulistyandary, Perlindungan Hukum Nasabah Korban Pembobolan Rekening (Bagian II), http://www.google.com, Diakses pada tanggal 3 Februari 2018. 